\title{
A Comprehensive Evaluation of Yacht Charter Service Concept: Influence of Voyager-to-Voyager Interaction on Service Satisfaction
}

\author{
() Neslihan Paker1, (1) 0sman Gök² \\ ${ }^{1}$ İzmir Kavram Vocational School, Department of Logistics Program, İzmir, Turkey \\ ${ }^{2}$ Yașar University, Department of Business Administration, İzmir, Turkey
}

\begin{abstract}
The study attempts to evaluate yacht charter service attributes considering the service quality, customer satisfaction, and loyalty three-leg framework. Besides visited destinations, the service concept is enlarged with social servicescape dimensions of interaction quality and customer similarity for a holistic approach. A self-administered questionnaire was provided to 359 customers, and the relationships in the research model were tested via structural equation modeling. The results showed that satisfaction depends on the interaction quality, which is strongly related to the similarity between other customers, as well as the quality of the service elements and the attractiveness of the visited destination. This study presents a pioneering research attempt focusing on the influence of customer-to-customer interaction and customer similarity on yacht charter services. Findings of the study provide a theoretical contribution, highlighting the importance of customer-to-customer interaction for service appraisals of customers. Theoretical and practical implications for interaction-dominant services are discussed.
\end{abstract}

\section{Keywords}

Customer-to-customer interaction, Service quality, Customer satisfaction, Services marketing, Marine tourism

\section{Introduction}

Every service provider must fully understand customer expectations of their service to be competitive in today's markets. In addition, it is difficult to convince customers of the superior value of a service because of its idiosyncratic characteristics. These challenges force academics and practitioners to consider service performance factors in a holistic manner and to examine the relationships between these factors through integrated research models. In services literature, the influences of physical facilities and employees on customer satisfaction have been examined for decades. However, the issue of other customers, an inevitable part of the social dimension of the service environment, needs discussion and should be exemplified [1-3]. With the rise in shared consumption, the issue of other customers' influence on the perceived service performance has attracted more attention, and this subject is considered a major concept in service quality studies.

The yacht charter service is a premium type of marine tourism product [4-6]. Despite significant socio-economic contributions to a national economy [7-9], it is rarely discussed in scientific literature. Chartering companies provide a variety of services from essential to luxury services (e.g., a masseur or sommelier) to be competitive in the market. However, like the pull factors related to the service, the intrinsic motivations of yacht charter customers have played a pivotal role in the service selection and evaluation process. Besides voyaging on the sea, customers also want to socialize with people having similar interests and develop friendships while sailing in untouched nature $[10,11]$. Therefore, whether acquainted or unacquainted, the other customers represent a major service attribute in

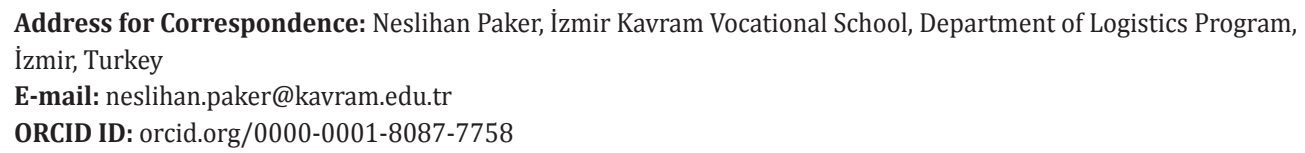

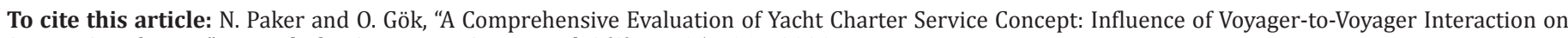
Service Satisfaction." Journal of ETA Maritime Science, vol. 9(3), pp. 157-167, 2021.

(C) Copyright 2021 by the Journal of ETA Maritime Science published by UCTEA Chamber of Marine Engineers 
the yacht chartering context. Thus, recent research proposes a holistic approach for yacht charter service concept, specifically to explore the influences of customer interaction and customer similarity on yacht service satisfaction.

To achieve our research objectives, the blue voyage (BV), which is a crewed type of yacht chartering, is used as a research subject. The BV has been arranged for more than 70 years in Turkey, which is a highly popular yachting destination in the Mediterranean Basin. Some prominent advantages, such as having a zigzag-shaped coastline and several sheltered coves, distinguish the BV from other yacht charters in various destinations. Generally, the voyage duration is one week, and the crew provides at least some services such as transportation, cooking, and housekeeping. The yacht is just large enough to enter bays; the voyagers share limited space. Thus, such a service setting can create an opportunity to observe the influence of customer interaction on satisfaction and makes the BV an ideal research context.

In the following section, we discuss the theoretical background of our study. We then describe the data collection and methodology of the fieldwork and present the findings. In the last section, we discuss the findings and touch upon the theoretical and management implications and potential avenues for future research.

\section{Background}

\subsection{Yacht Charter Services Attributes}

The defining attributes of a concept or a product has been widely used in literature for different purposes such as measuring the service quality or customer satisfaction. Considering studies in the hospitality and marine tourism industry, the attributes of yacht charter services can be mainly categorized as physical environment, services, and employees, which are service performance indicators [1217].

Apart from transporting passengers safely, the essential services given in a yacht include housekeeping and food and beverage that customers expect to be provided at a highquality level. Since the yacht is far from the shore during the largest part of the tour, the quality of food onboard is highly important for customers. It is possible to see exclusive examples of international cuisine on luxury yachts, as well. In recent years, because of the increase in the healthy eating trend, the customer demand for food with organic ingredients has increased significantly. Cleaning is one of the most important elements in the yacht industry and significantly impacts customer satisfaction. Furthermore, some yachts, like hotels, have many executions such as arranging towels or deck decoration.
Yachts are physical service environments where all relevant services are provided. They provide not only safe transportation but also a comfortable holiday experience. Furthermore, flippers, snorkel, and fishing tackle are available in almost all yachts. In more luxurious yachts, there is a wide range of water toys, such as canoe, sup, inflatable slide, ringo, water bird, and wake surfing. Moreover, some of the tours include yoga activities. The crew is a crucial part of the yacht, expected to be clean, reliable, respectful, willing to serve, and competent at their jobs. The tour can be completed in a pleasant way thanks to the mastery of the staff.

\subsection{Pull Factors of Destination as Attributes of Yacht Charter Concept}

The destination is a significant determinant element for tourists when choosing a service. Related literature has focused on two interrelated factors [18] as decision-making inputs of a tourist to select a destination: pull and push. Several studies have suggested a significant relationship between the attributes of destination and customer satisfaction $[19,20]$.

Marine tourism products such as cruising, yachting, whale watching, and sunbathing cannot be arranged if the destination, as a part of the service offered, is ignored. The authors of [21] pointed out that the destination is yachters' first decision-making criterion for sailing. Anchoring in safe locations is as important for pleasure yachters as is traveling to attractive places. Based on the findings of [11], safety is one of the most important pull factors of marinas. Similar to marinas, bays can also be considered a type of natural harbor, providing safety on the sea in addition to being naturally attractive.

\subsection{Customer-to-customer Interaction and Similarity to Other Customers}

The influence of other customers is the most challenging aspect of offering services because it is uncontrollable [22]. Several researchers have claimed that this influence is a tangible clue or a part of physical evidence that facilitates evaluation of the service performance $[1,23]$. Many studies have revealed that this indicator affects the perceived value, service quality, customer satisfaction, customer retention, and value creation process [2,24,25]. Although it is an integral part of service experience, little academic attention has been paid to the impact of other customers on customers' service evaluations $[25,26]$.

Scholars have discussed customer-to-customer interaction (CCI) from two opposite perspectives. The first is concerned about customers' unsuitable behaviors [25,27], while the other is the social benefit gained from developed friendships with others. Hence, the main aim of CCI is to 
prevent disturbing situations while providing healthy social interaction opportunities in the service environment. Some scholars have also examined the negative side of CCI that affects satisfaction. For example, in [25], 21 CCI interaction incidents were measured, and six factors (i.e., "protocol and sociable," "violent," and "crude") were obtained, some of which are highly correlated with customer satisfaction. On the other hand, the positive side of CCI is mostly defined by spending enjoyable time with others and developing friendship dimensions [22,28].

The similarity or homogeneity concepts are also addressed along with the CCI concept. The similarity is assumed to affect interaction possibility, willingness to interact with each other, customer satisfaction, and even loyalty toward the service provider [29]. In this context, age, sex, marital status, race, religion, and educational background characteristics are mostly examined as similarity attributes in qualitative studies [24,25]. The authors of [30] pointed out that similarity among customers increases satisfaction in a shopping mall even if there is no connection among customers. The authors of [3] also suggested that customer similarity increases repurchase intentions. The authors of [31] reported that the presence of old customers affects young adults' attitudes negatively with respect to purchase intention and service quality perception in health clubs and restaurants. The authors of [24] and [32] argued that individuals feel better when around others who are similar to them. Moreover, the authors of [33] claimed that cruise passengers feel more comfortable in the service environment if the passengers have similar interests and backgrounds. The authors of [25] claimed that as time spent together increases, homogeneity has more effect on satisfaction. The authors of [34] stated that the intensity and amount of time spent together has a positive effect on interaction in the cruise industry. Furthermore, the authors of [24] and [34] emphasized the crucial importance of compatibility when other customers are expected to share, there is close physical proximity among customers, and a high probability of conversation exists among customers in the service environment.

\subsection{Service Quality, Customer Satisfaction, and Loyalty}

Service performance has been measured via service quality (SQ) constructs (e.g., SERVQUAL and SERVPERF) in the services industry since the 1980s. Customer satisfaction (CS), which is an emotional evaluation of service experience [35] and a noteworthy determinant of loyalty (LY), has been implied by marketing concepts with SQ across studies. Many studies have suggested that SQ is an antecedent of CS and LY $[36,37]$ and that a strong relationship exists between CS and LY [38,39].
In [40], a pioneering study was reported, examining the relationships between these constructs in the services industry. Their research offers empirical evidence that $S Q$ is positively associated with CS, and CS influences willingness to reuse overnight hospital care services. The authors of [41] tested the links between SQ, CS, and LY for the banking, dry cleaning, fast food, and pest control industries. Their results suggest that $\mathrm{SQ}$ is an antecedent of CS, and CS has a more substantial influence on LY than SQ.

Hospitality and marine tourism studies have also reached similar results. For instance, a study on the hotel industry reveals that $S Q$ is positively related to CS [35]. Studies have shown a link between perceived SQ, satisfaction, and repurchase intention of Hong Kong [17] and North American [13] cruise travelers, and Red Sea yacht tourists [42]. Furthermore, [12] a study on cruise tourist behaviors showed that interactional quality and outcome quality affect satisfaction and loyalty. Generally, CS is described as a moderating variable between SQ and LY [40]. Along with this role, several studies have pointed out that CS serves a mediating function between SQ and LY [43].

\section{Research Design}

\subsection{Blue Voyage Case}

The most prominent destinations for the yachting industry have traditionally been Caribbean Islands and Spain, Italy, Greece, France, Croatia, and Turkey in the Mediterranean Basin. Turkey has long, zigzag-shaped shorelines, a long season for yachting from April to October, well-safe bays, and suitable seas for swimming, and tourist hot spots, such as the Lycian Way and Cleopatra Beach, which differentiate it from other destinations. The BV is a crewed yacht charter, and it has been offered along the west and south parts of Turkey for more than 70 years. This charter is a one week voyage, and transportation, housekeeping, and cooking are the essential services the crew provides. The gulet-type yacht is preferred, which is wooden and specific to Turkey, and it is sufficiently long to enter bays. The yacht generally has eight cabins with double beds, plus crew quarters, making it big enough for approximately 20 persons, including the crew. The voyage can be either exclusive or a cabin charter. The exclusive yacht charter requires that a group of customers rents all the cabins. The customers can be family members or friends. In the cabin charter, customers are unacquainted people who buy the tour from the yacht company independently. The voyagers experience intense interaction while on the yacht for both types of charters. Sometimes, new friendships are formed and existing ones are developed. In some cases, customers from different nations create cultural exchange opportunities on the yacht. 


\subsection{Questionnaire Development}

A total of 12 semistructured interviews with experienced $\mathrm{BV}$ customers were conducted to define the yacht charter concept service-specific attributes that impact service evaluation. The first author directed the interviews, and five hours of data were recorded. The respondents stated the yacht rental services' components under six main categories: crew, yacht, gastronomy, activity, destination, and other customers. Thereafter, the constructs were integrated into the model to evaluate yacht charter services, and a questionnaire was designed as a survey instrument based on interview findings and accumulated literature review. Most of the questionnaire items were adapted from literature i.e., [12,13,28,30,32,34,44-46]. The rest of the items are service-specific items based on interview findings (i.e., "The yacht had enough space in shared areas such as on deck and at the dining table., "Bays of the BV destination were quiet and peaceful," "The other customers and I had a similar lifestyle" The other customers had a similar educational level to mine"). Detailed information on the questionnaire constructs is listed in Table 1. Figure 1 depicts the research model. We hypothesize as follows:

H1: Crew attributes are positively related to overall service quality (OSQ).

H2: Yacht attributes are positively related to OSQ.

H3: Gastronomy attributes are positively related to OSQ.
H4: Activity attributes are positively related to OSQ.

H5: Interaction with other customers is positively related to OSQ.

H6: Similarity with other customers (SOC) is positively related to interaction with other customers (CCI).

H7: CCI is positively related to customer satisfaction (CS).

H8: Destination attributes are positively related to CS.

H 9: OSQ is positively related to CS.

H10: CS is positively related to loyalty (LY).

H11: OSQ is positively related to LY.

H12: CS mediates the relationship between OSQ and LY.

The questionnaire had seven main parts. The first part aimed to collect information on the customers' last BV experience and socio-demographics. Subsequently, the quality of gastronomy, activities, crew, yacht, destination, interaction, OSQ SOC, satisfaction with cruise experience, and loyalty, respectively, were questioned. All the measurement items of the questionnaire were designed as a seven-point Likerttype scale ranging from 1 (= strongly disagree) to 7 (= strongly agree).

Before conducting the survey, the questionnaire was checked via face validity methods. Four tourism/marketing academics and two experienced industry representatives evaluated the questionnaire considering the research purposes. They concurred that the questionnaire can

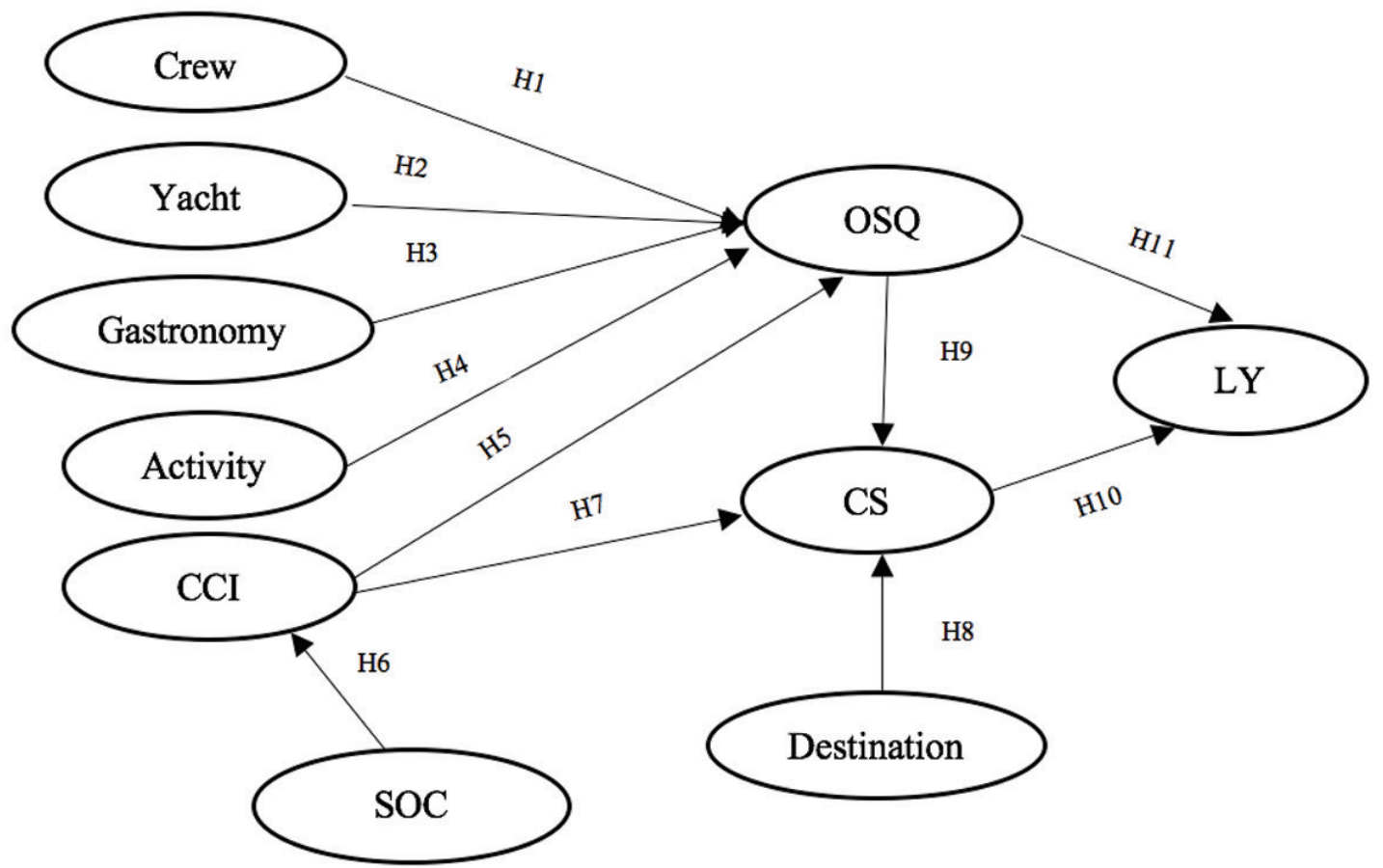

Figure 1. Research model

CCI: Customer-to-customer interaction, SOC: Similarity with other customers, LY: Loyalty, OSQ: Overall service quality, CS: Customer satisfaction 
Table 1. Scales

\begin{tabular}{|c|c|}
\hline Constructs & Items \\
\hline $\begin{array}{l}\text { Activities } \\
\text { adapted from }[12,13]\end{array}$ & $\begin{array}{l}\text { - A variety of sports activities was organized (i.e., fishing, diving, cycling, trekking). } \\
\text { - A variety of intellectual activities was offered (i.e., historical and gourmet tours, sailing lessons). } \\
\text { - A variety of entertainment activities was arranged (i.e., animations, dance parties, night tours). }\end{array}$ \\
\hline $\begin{array}{l}\text { Destination } \\
\text { adapted from }[13,45]\end{array}$ & $\begin{array}{l}\text { - Bays of the blue voyage destination were safe. } \\
\text { - Bays of the blue voyage destination were quiet and peaceful. } \\
\text { - Bays of the blue voyage destination had green shorelines. } \\
\text { - Sea in the bays had a natural attractiveness. }\end{array}$ \\
\hline $\begin{array}{l}\text { Crew } \\
\text { adapted from [44] }\end{array}$ & $\begin{array}{l}\text { - The crew was neat and clean. } \\
\text { - The crew provided service reliably, consistently, and dependably. } \\
\text { - The crew was willing and able to provide service in a timely manner. } \\
\text { - The crew was competent (i.e., knowledgeable and skillful). } \\
\text { - The crew was approachable and easy to contact. } \\
\text { - The crew was courteous, polite, and respectful. } \\
\text { - The crew listened to me and spoke in a language that I could understand. } \\
\text { - The crew made the effort to understand my needs. }\end{array}$ \\
\hline $\begin{array}{l}\text { CCI } \\
\text { adapted from }[28,32]\end{array}$ & $\begin{array}{l}\text { - I developed or enhanced friendships with the other customers. } \\
\text { - I enjoyed spending time with the other customers on the yacht. } \\
\text { - The other customers made my time there more enjoyable. }\end{array}$ \\
\hline $\begin{array}{l}\text { CS } \\
\text { adapted from [12] }\end{array}$ & $\begin{array}{l}\text { - Overall, I was satisfied with this blue voyage experience. } \\
\text { - Overall, this BV put me in a good mood. } \\
\text { - I really enjoyed myself at this blue voyage. }\end{array}$ \\
\hline $\begin{array}{l}\text { LY } \\
\text { adapted from [44] }\end{array}$ & $\begin{array}{l}\text { - I will use this blue voyage company's services again. } \\
\text { - If I had to do it over again, I would make the same company choice. } \\
\text { - I will recommend this blue voyage company to a friend. } \\
\text { - I tell other people positive things about this blue voyage company. }\end{array}$ \\
\hline
\end{tabular}

measure the related factors, and they also provided constructive recommendations. Moreover, 12 customers with BV experience pre-tested it. Unclear questions were restructured to eliminate ambiguity. Two linguists and two academics, one of whom was competent in marketing, also performed English proofreading of the survey. They also checked English-Turkish and Turkish-English translations for slippage and made necessary corrections.

\subsection{Sampling Process and Profile of the Sample}

The survey was conducted in the most popular destinations of BV (i.e., Bodrum, Marmaris, and Fethiye) between 
June 2018 and August 2018, and 359 fully answered questionnaires were obtained. The convenience sampling method was preferred to reach as many respondents as possible considering accessibility difficulties to the sample.

Blue voyagers generally span several age groups. However, $89.1 \%$ of the respondents were older than 30 . The respondents' marital status was mostly married/living together $(74.4 \%)$, and gender was distributed almost equally. Most participants were Turkish (77.4\%). Moreover, $87.5 \%$ had at least a university/college degree. Almost all the respondents had mid-level or higher incomes based on their country's income scale. Approximately half of the respondents defined their income level as high or above. The respondents enjoyed a working status (75.8\%), and $71 \%$ of them go on vacations at least thrice or thrice a year. The respondents had largely the same amount of experience (first participation in BV), had taken two to three BV excursions, or have had four or more experiences with BV.

\subsection{Measurement Validation}

\subsubsection{Common Method Variance}

Three different techniques were used to check for common method variance (CMV) in the study. First, Harman's onefactor test was used. All constructs of the study were examined via principal component analysis using an unrotated factor solution. Six factors were obtained. The single construct accounted for no more than $50 \%$ of the variance. A single factor model was also tested. All the measurement items were forced to load a single factor via confirmatory factor analysis (CFA). The fit indices were considerably worse for the one-dimensional model than for the measurement model. Moreover, the marker variable technique (unrelated marker variable) was tested. Using a theoretically unrelated marker variable, the CMV-adjusted correlations were compared with the unadjusted matrix using partial correlation analysis via SPSS. The unrelated marker variable was taken from Fuchs and Reichel's [46] perceived risk scale: "I worried that participating in BV would change the way my family think of me." A small correlation was observed between the marker variable and substantive constructs (i.e., <0.394). The initially significant correlations remained unchanged after adjusting for CMV. Moreover, small correlation value differences exist between the adjusted and unadjusted matrices (i.e., <0.093). As a result, common method bias is not a likely threat to the results of our study.

\subsubsection{Confirmatory Factor Analysis}

The research model was tested via CFA using AMOS 24. Items those were cross-loaded or loaded to their factors lower than 0.50 were eliminated from the constructs. Moreover, the correlations between constructs were evaluated for discriminant validity violations. The measurement model provided satisfactory results: average variance extracted (AVE) $>0.50$, construct reliability (CR) $>0.7$, AVE $>$ maximum shared variance (MSV), and Cronbach's alpha $>0.7$ for all constructs. Moreover, the results revealed sufficiently high loadings per item per construct $(>0.620)$, and all factor loadings were statistically significant. Therefore, both the convergent validity and discriminant validity of the constructs were strongly supported and the item reliability of the scales was confirmed. Normality testing showed that the skewness of each variable was below 3.0 and that the kurtosis of each variable was below 10.0; therefore, a normality assumption was supported [12] as well. Moreover, standardized residuals were examined. Only two pairs of variables were slightly above the cutoff value (i.e., 4.3 ), and the rest were below 4.0. CFA results indicated a sufficient fit to the data $(\varkappa 2=1342, \mathrm{df}=684, \mathrm{p}<0.001, \varkappa 2 /$ $\mathrm{df}=1.963, \mathrm{NFI}=0.927, \mathrm{IFI}=0.963, \mathrm{TLI}=0.957, \mathrm{CFI}=0.963$, RMSEA $=0.052$ ).

Tables 2 and 3 present detailed information on the constructs, and the reliability and validity results of the measurement model.

\section{Analysis and Findings}

The structural equation modeling analysis was employed to test the proposed model and hypotheses via AMOS 24. The goodness-of-fit statistics of the proposed model revealed that the model could reasonably fit the data $(\varkappa 2=1538, \mathrm{df}=703, \mathrm{p}<0.001, \varkappa 2 / \mathrm{df}=2,189, \mathrm{NFI}=0.916$, $\mathrm{IFI}=0.953$, TLI $=0.947, \mathrm{CFI}=0.953$, RMSEA $=0.058)$. While crew $(\beta=0.540, p<0.001)$, yacht $(\beta=0.251, \quad p<0.001)$, gastronomy $(\beta=0.104, p<0.05)$, and activity $(\beta=0.113$, $\mathrm{p}<0.05)$ significantly affect OSQ, CCI $(\beta=0.02, \mathrm{p}>0.05)$ does not. Crew is by far the most important factor having an effect on SQ, and yacht ranked second in importance to SQ following crew. Thus, $\mathrm{H} 1, \mathrm{H} 2, \mathrm{H} 3$, and $\mathrm{H} 4$ were supported, and $\mathrm{H} 5$ was rejected. $\mathrm{SOC}(\beta=0.464, \mathrm{p}<0.001)$ was positively related with CCI. Thus, $\mathrm{H} 6$ received strong support. CCI $(\beta=0.161, p<0.001)$, destination $(\beta=0.388, p<0.001)$, and OSQ $(\beta=0.393, p<0.001)$ were significant predictors of CS and thus H7, H8, and $\mathrm{H} 9$ were supported. $\mathrm{CS}(\beta=0.313$, $\mathrm{p}<0.001)$ and OSQ $(\beta=0.621, \mathrm{p}<0.001)$ were positively associated with LY, so H10 and H11 were supported. Moreover, the mediation effect in the model was also tested. The bootstrapping method (bootstrap=2000) was used to test the mediating effects of CS on the relationships between OSQ and LY; the bootstrapping indicated that CS partially mediates the effects of OSQ on $\mathrm{LY}(\beta=0.126$, $\mathrm{p}<0.001)$. Thus, $\mathrm{H} 12$ was supported. Figure 2 shows the related results. 


\section{Discussion}

In this study, we attempted to evaluate the influence of yacht charter service concept attributes, specifically customer interaction and similarity, on SQ and CS. BV is a relevant research context as its duration and service environment make it possible to gage social interaction between customers and its effect on satisfaction. We put forward 12 hypotheses based on the literature and qualitative research findings, and 11 were supported.

The results revealed that the crew is the most crucial element of overall OSQ followed by yacht, activities, and gastronomy. In [47], the authors emphasized that employees have sometimes been considered the service itself. Hence, crew' behaviors and competencies have crucial importance for the concept. Moreover, considering the limited-service environment, their receptiveness toward customers' privacy needs will positively affect SQ. The findings also indicate that cabin comfort (i.e., size, air condition, and equipment) is another essential factor of the yacht charter SQ. Moreover, the yacht should have required warnings and information to create a risk-free environment and have sufficient space in shared areas such as the deck and dining table. The food quality onboard is highly essential for customers. Besides, offering activities in various may positively influence OSQ.

In contrast to literature [48], other customers did not significantly affect consumers' SQ perceptions. Rather, the presence of other customers may have had a direct effect on CS. The lack of influence of other customers on the SQ can be explained by considering the type of yacht charter service purchased. In exclusive yacht charter, customers decide on the other participants, which can be family members or friends. Thus, they might consider that since other customers have not been provided by the company, they may not affect the SQ compared with other attributes. However, in cabin charter, customers are unacquainted people who purchase the tour from the yacht company independently. Like in Poland [49], there is price-based competition in the Turkish yacht charter market. Hence, the priority of yacht charter companies is to fill the yacht

Table 2. Correlations and descriptive statistics

\begin{tabular}{|c|c|c|c|c|c|c|c|c|c|c|c|c|}
\hline Constructs & Mean & Standard deviation & 1 & 2 & 3 & 4 & 5 & 6 & 7 & 8 & 9 & 10 \\
\hline Gastronomy & 5.84 & 1.19 & 1.0 & & & & & & & & & \\
\hline Activities & 3.48 & 1.97 & .25 & 1.0 & & & & & & & & \\
\hline Yacht & 5.04 & 1.48 & .57 & .47 & 1.0 & & & & & & & \\
\hline Destination & 6.10 & 1.06 & .67 & .19 & .56 & 1.0 & & & & & & \\
\hline Crew & 5.90 & 1.36 & .66 & .31 & .69 & .72 & 1.0 & & & & & \\
\hline CCI & 6.13 & 1.19 & .44 & -.01 & .26 & .49 & .44 & 1.0 & & & & \\
\hline OSQ & 5.33 & 1.53 & .62 & .41 & .74 & .55 & .79 & .31 & 1.0 & & & \\
\hline SOC & 5.69 & 1.31 & .12 & -.05 & .07 & .10 & .12 & .41 & .16 & 1.0 & & \\
\hline CS & 6.19 & 1.16 & .55 & .14 & .53 & .61 & .71 & .44 & .65 & .17 & 1.0 & \\
\hline$L Y$ & 5.69 & 1.71 & .51 & .34 & .64 & .51 & .76 & .32 & .80 & .12 & .73 & 1.0 \\
\hline
\end{tabular}

Table 3. Reliability and validity statistics

\begin{tabular}{|c|c|c|c|c|}
\hline Constructs & $\alpha$ & CR & AVE & MSV \\
\hline Gastronomy & .86 & .88 & .71 & .57 \\
\hline Activities & .86 & .86 & .68 & .29 \\
\hline Yacht & .85 & .86 & .62 & .58 \\
\hline Destination & .87 & .87 & .64 & .60 \\
\hline Crew & .97 & .97 & .83 & .68 \\
\hline $\mathrm{CCI}$ & .93 & .94 & .84 & .21 \\
\hline OSQ & .96 & .96 & .89 & .68 \\
\hline SOC & .93 & .92 & .70 & .21 \\
\hline CS & .98 & .97 & .91 & .53 \\
\hline LY & .98 & .98 & .93 & .67 \\
\hline
\end{tabular}




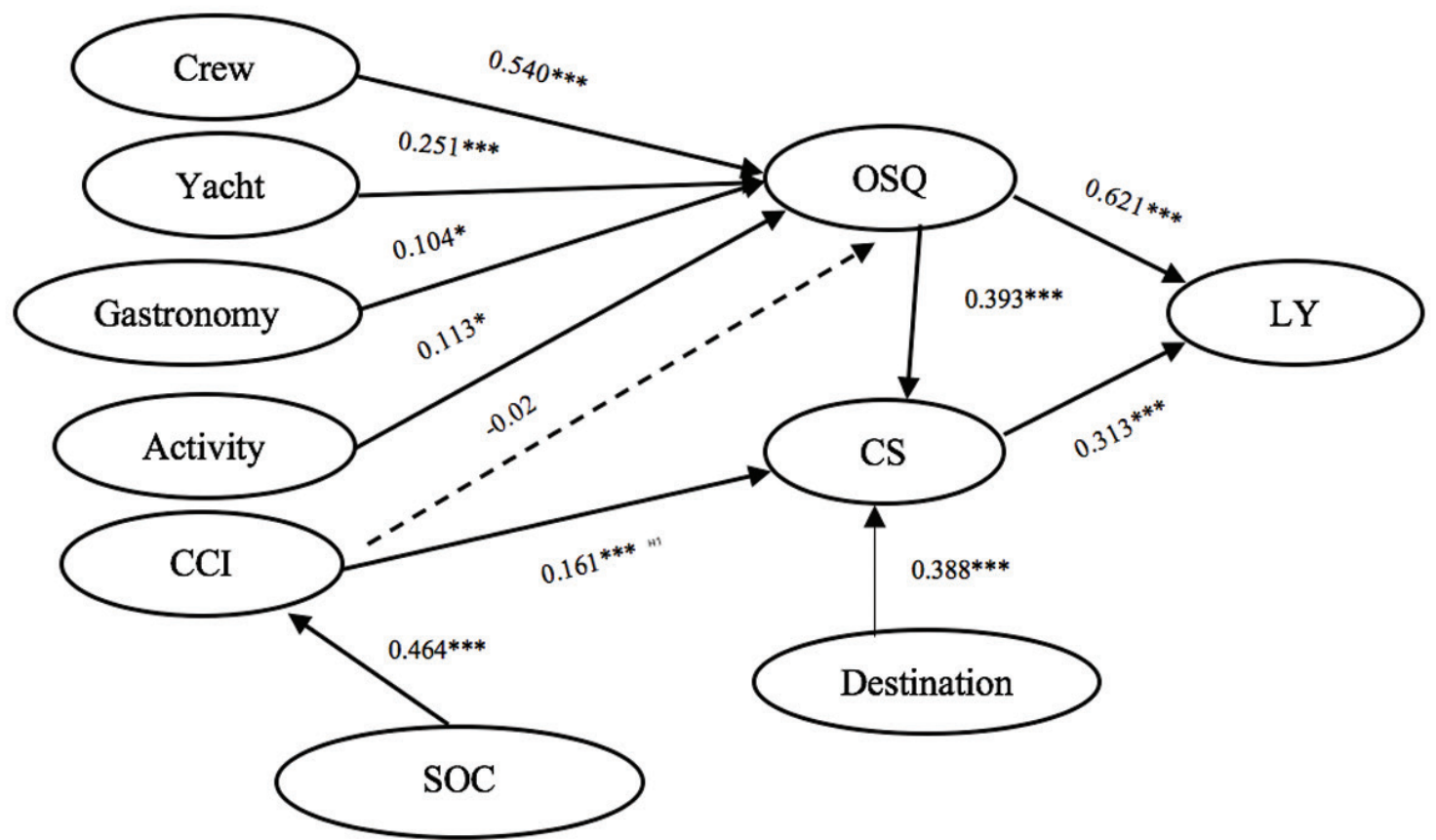

Figure 2. Structural model results

${ }^{*} p<0.05,{ }^{* * *} p<0.001$

$\rightarrow$ Statistically significant

$-\mathbf{-}-\mathbf{-}-\mathbf{-}-\rightarrow$ Statistically insignificant

CCI: Customer-to-customer interaction, SOC: Similarity with other customers, LY: Loyalty, OSQ: Overall service quality, CS: Customer satisfaction

capacity, and it is generally not known which customers will share the same yacht until the last moment. For this reason, cabin charter customers may not have seen this element as a significant factor in their SQ expectations, since they are not provided with clear information on the other customers beforehand.

OSQ served as an antecedent of customer satisfaction and loyalty and had a greater effect on LY than CS. Generally, the opposite is expected, but some prior studies have reached similar results [43]. The BV customer might think that loyalty to service providers depends on the SQ the company provides. Moreover, the authors found that CS partially mediates the effects of overall SQ on LY. Several extant studies also suggest that CS plays a mediating role between SQ and LY $[37,38,50]$.

Moreover, the destination factor is a strong influencer of CS, and this finding is consistent with several studies in the literature e.g., $[19,20,51]$. The service concept's unique side is the quiet and peaceful bays in the destination. The crowding at the bays might negatively affect destination attractiveness. Hence, managing and controlling the crowding is strongly suggested the service managers. BV destination publicity should be undertaken via brochures or promotional films that inform the voyagers about the destination attractions. Crew training on destination may increase CS.

CCI is a significant factor for CS, which is specifically examined in the study. BV is an interaction-dominant tourism concept that requires living in a limited space with several people for a relatively long period. That is, many interactions occur in the BV service environment, which triggers co-creation of value [2]. These results are in line with studies confirming a strong relationship between $\mathrm{CS}$ and $\mathrm{CCI}[22,25]$. Our findings also reveal that the significance of $\mathrm{CCI}$ on satisfaction varies depending on the industry. Studies conducted on cruise customers also show that the CCI's effect on satisfaction was implicit [34] or had only an indirect effect [27,12]. There are hardly any studies investigating the service expectations of yacht tourism customers. It can be considered that yacht tourism should be examined under the cruise tourism context. However, while the limited customers experience the service together almost all the time in a small yacht in a yacht charter, thousands of people are hosted on a huge ship in a cruise environment. The yacht charter customers described the components of service experience as a triangle of nature, other people, and the services offered on the yacht. In other service contexts, such as hospitality, restaurant, or cruise, a relationship may only be established 
with other customers coincidentally. The authors of [34] stated that cruise customers have little interest in socializing with other customers. Nevertheless, meeting new people and developing friendships is essential for yacht customers [11], and the yacht charter provides such an environment where people can get to know other people and introduce themselves like never before. Therefore, a recent study provides a theoretical contribution indicating the sectorspecific importance of the CCI concept.

The findings reveal that similarity between customers is positively related to $\mathrm{CCI}$. The authors of [32] suggested that the perception of homogeneity in CS is more important on long trips and the influence of homogeneity on CS will obviously increase. Furthermore, studies on similarity and CCI are rare in the relevant literature and have mostly employed qualitative methods. Our study validates some similarity features in the literature and adds education level and life style as other similarity features that have rarely been tested in prior studies.

Although it is challenging to control, managers should consider that the customer interaction dimension is vital for service satisfaction. As customers' similarity increases, social interaction is enhanced and their satisfaction increases accordingly. The similarity concept involves age, education, and lifestyle for the yachters. Generally, the yachters are well-educated, and they may want to involve intellectual interaction while on the yacht. Furthermore, the yacht charter is a premium type of tourism product; therefore, uniqueness cannot be created solely by physical service elements. The yachters are highly experienced tourists, and they do not want to compromise on fundamentals such as feeling peaceful amidst nature. Customer similarity can establish a more comfortable environment and customers can relax easily under these conditions. Thus, customer segmentation tools can be used to match the most compatible voyagers. For example, online platforms can provide information to voyagers to find other customers having similar characteristics.

Since BV is a high-contact service context, crew training is imperative to provide top-level hospitality. The crew should also handle consumer interactions in the yacht, and they sometimes take on the initiator role to start relationships in the group.

\section{Conclusion}

Like many other researches in relevant literature, the sample size and customer variety regarding nationality are noticeable limitations of this study. Internationally diverse and larger samples may provide more generalizable insights. Our results emphasize again that voyagers have different expectations, and the yacht market has several segments. Future segmentation studies have the potential to develop better BV services and to design better target marketing practices. Furthermore, the customer similarity scale can be further studied with different characteristics to reach service-specific similarities. Future studies can also investigate the antecedents and outcomes of CCI in other nature-based contexts such as caravan campers.

\section{Ethics}

Ethics Committee Approval: Ethics committee approval was obtained from Yaşar University Social Sciences Institute (date: 01/06/2018, no: 5200).

\section{Authorship Contributions}

Data Collection or Processing: N. Paker, Analysis or Interpretation: N. Paker, O. Gök, Literature Review: N. Paker, O. Gök, Writing, Reviewing and Editing: N. Paker, O. Gök.

Funding: The authors declared that this study received no financial support.

\section{References}

[1] L. Miao, A.S., Mattila and D. Mount, "Other consumers in service encounters: A script theoretical perspective," International Journal of Hospitality Management, vol. 30, pp. 933-941, December 2011.

[2] I. Rihova, D. Buhalis, M. Moital and M.B. Gouthro, "Conceptualising customer-to-customer value co-creation in tourism," International Journal of Tourism Research, vol.17, pp. 356-363, Jan 2015.

[3] L. Hanks and N. Line, "Perceived similarity in third places: Understanding the effect of place attachment, "International Journal of Hospitality Management, vol. 86, pp. 102455, Apr 2020.

[4] A. Alcover, M. Alemany, M. Jacob, M. Payeras, A. Garcia and L.M. Ribes, "The economic impact of yacht charter tourism on the Balearic economy," Tourism Economics, vol.17, pp.625-638, Jun 2011.

[5] R. Alkier, "Perspectives of development of luxury nautical tourism in the Republic of Croatia," Pomorski Zbornik, vol. 56, pp. 109-124, 2019.

[6] S.A.K. Ioannidis, "An overview of yachting tourism and its role in the development of coastal areas of Croatia," Journal of Hospitality and Tourism Issues, vol.1, pp. 30-43, Dec 2019.

[7] M.L. Miller and J. Auyong, "Coastal zone tourism. A potent force affecting envirionment and society," Marine Policy, pp.75-99, Mar 1991.

[8] S.C. Chen, M.C. Wu, and C.H. Chen, “Employee's personality traits, work motivation and innovative behavior in marine tourism industry," J. Service Science \& Management, vol.3, pp.198-205, June 2010.

[9] F. Sevinç and T. Güzel, "Sustainable yacht tourism practices," Management \& Marketing, vol. 15, pp.61-76, Oct 2018.

[10] M. Orams, Marine tourism: development, impacts and management, London \& New York: Routlege, 1999. 
[11] N. Paker, and C.A. Vural, "Customer segmentation for marinas: evaluating marinas as destinations," Tourism Management, vol. 56, pp.156-171, Oct 2016.

[12] B.L. Chua, S. Lee, B. Goh and H. Han, "Impacts of cruise service quality and price on vacationers' cruise experience: moderating role of price sensitivity," International Journal of Hospitality Management, vol. 44, pp.131-145, Jan 2015.

[13] V.B. Teye and D. Leclerc, "Product and service delivery satisfaction among North American cruise passengers" Tourism Management, vol.19, pp.153-160, Apr 1998.

[14] R.J. Kvortnic, "Shipscape influence on the leisure cruise experience. International Journal of Culture," Tourism and Hospitality Research, vol. 2, pp. 289-311, Oct 2008.

[15] H.J. Xie, D.L. Kerstetter and A.S. Mattila, "The attributes of a cruise ship that influence the decision making of cruisers and potential cruisers," International Journal of Hospitality Management, vol. 31, pp. 152-159, Mar 2012.

[16] J. Hwang and H. Han, "Examining strategies for maximizing and utilizing brand prestige in the luxury cruise industry," Tourism Management, vol. 40, pp. 244-259, Feb 2014.

[17] H. Qu and E.V.Y. Ping, "A service performance model of Hong Kong cruise travelers motivation factors and satisfaction," Tourism Management, vol. 20, pp. 237-244, Apr 1999.

[18] K.S. Chon, "Understanding recreational traveler's motivation, attitude and satisfaction," The Tourist Review, vol. 44, pp. 3-7, Jan 1989.

[19] Y. Yoon, and M. Uysal, "An Examination of The Effects of Motivation And Satisfaction on Destination Loyalty: A Structural Model," Tourism Management, vol. 26, pp. 45-56, Feb 2005.

[20] M. Devesa, M. Laguna and A. Palacios, "The role of motivation in visitor satisfaction: empirical evidence in rural tourism", Tourism Management, vol. 31, pp. 547-552, Aug 2010.

[21] E. D. Eris, "Uluslararası pazarlarda Türk marinalarının çekiciligi ve pazarlama Stratejileri," Ege Akademik Bakıs, vol.7, pp. 37-55, 2007.

[22] J. Yoo, T.J. Arnold, and G.L. Frankwick, "Effects of positive customer-to-customer service interaction," Journal of Business Research, vol. 65, pp. 1313-1320, Sept 2012.

[23] C. Lovelock and L. Wright, Principles of Service Marketing and Management. 2nd ed. New Jersey: Prentice Hall, 2002.

[24] C.L. Martin, and C.A. Pranter, "Compatibility management: customer-to-customer relationships in service environments," Journal of Services Marketing, vol. 3, pp. 5-15, Mar 1989.

[25] C.H.J. Wu, "The impact of customer-to-customer interaction and customer homogeneity on customer satisfaction in tourism service-The service encounter prospective," Tourism Management, vol. 28, pp. 1518-1528, Dec 2007.

[26] W. Wei, Y.T. Lu, L. Miao, L.A. Cai, and C. Wang, "Customercustomer interactions (CCIs) at conferences: an identity approach," Tourism Management, vol. 59, pp.154-170, Apr 2017.

[27] J. Huang and C.H.C. Hsu, "The impact of customer-to-customer interaction on cruise experience and vacation satisfaction," Journal of Travel Research, vol. 49, pp. 79-92, May 2009.

[28] R. Moore, M.L. Moore, and M. Capella, "The impact of customerto-customer interactions in a high personal contact service setting," Journal of Services Marketing, vol.19, pp.482-491, Dec 2005.

[29] A.D. Brack, and M. Benkenstein, "Responses to other similar customers in a service setting - analyzing the moderating role of perceived performance risk," Journal of Services Marketing, vol.28, pp.138-146, May 2014.

[30] H. Kwon, S. Ha and H. Im, "The impact of perceived similarity to other customers on shopping mall satisfaction," Journal of Retailing and Consumer Services, vol. 28, pp. 304-309, Jan 2016.

[31] M.V. Thakor, R. Suri and K. Saleh, "Effects of service setting and other consumers' age on the service perceptions of young consumers." Journal of Retailing, vol. 84, pp. 137-149, Jun 2008.

[32] E.D. Brocato, C.M. Vooerhees, and J. Baker, "Understanding the influence of cues from other customers in the service experience: a scale development and validation," Journal of Retailing, vol.88, pp.384-398, Sept 2012.

[33] S.S. Hyun and H. Han, "Luxury cruise travelers: other customer perceptions," Journal of Travel Research, vol. 54, pp. 107-121, Dec 2013.

[34] A. Papathanassis, "Guest-to-guest interaction on board cruise ships: Exploring social dynamics and the role of situational factors," Tourism Management, vol. 33, pp. 1148-1158, Oct 2012.

[35] H.H. Hu, J. Kandampully and T.D. Juwaheer, "Relationships and impacts of service quality, perceived value, customer satisfaction, and image: an empirical study, "The Service Industries Journal, vol.29, pp.111-125, Feb 2009.

[36] M.D. Richard and A.W. Allaway, "Service quality attributes and choice behavior," Journal of Services Marketing, vol. 7, pp. 59-68, Jan 1993.

[37] C-V. Priporas, N. Stylos, L.N. Vedanthachari and P. Santiwatana, "Service quality, satisfaction, and customer loyalty in Airbnb accommodation in Thailand," International Journal of Tourism Research, vol. 19, pp. 1-12, Aug 2017.

[38] A. Caruana, "Service loyalty: The effects of service quality and the mediating role of customer satisfaction," European Journal of Marketing, vol. 36, pp. 811-828, Aug 2002.

[39] F. Bilika, M.Safari and S. Mansori, "Review of Empirical Studies of Service Quality, Customer Satisfaction, and Loyalty, "Journal of Marketing Management and Consumer Behavior, vol.1, no.2, pp.1-11, 2016.

[40] A.G. Woodside, L.L. Frey and R.T. Daly, "Linking Service Quality, Customer Satisfaction, and Behavioral Intention" Journal of Health Care Marketing, vol. 9, pp. 5-17, Dec 1989.

[41] J.J. Cronin and S.A. Taylor, "Measuring service quality: a reexamination and extension, "Journal of Marketing, vol. 56, pp. 55-68, Jul 1992.

[42] W.A. Elias, F.M. Ahmed and M. Ezzat, "Assessing the tourists satisfaction towards yacht tourism services in the red sea coast, Egypt,", Minia Journal of Tourism and Hospitality Research, vol. 9, pp. 157-170, Jun 2020

[43] T.S. Dagger, J.C. Sweneey and L.W. Johnson, "A hierarchical model of health service quality scale development and investigation of an integrated model," Journal of Service Research, vol.10, pp.123142, Nov 2007.

[44] J.J. Cronin, M.K. Brady and G.T.M. Hult, "Assessing the effects of quality, value, and customer satisfaction on consumer behavioral 
intentions in service environments, "Journal of Retailing, vol.76, pp.193-218, Summer 2000.

[45] S. Baloglu and M. Uysal, "Market segmentation of push and pull motivations: a canonical correlation approach," International Journal of Contemporary Hospitality Management, vol. 8, pp. 3238, Jun 1996.

[46] G. Fuchs and A. Reichel, "Tourist destination risk perception: the case of Israel," Journal of Hospitality \& Leisure Marketing, vol. 14, pp. 83-108, Oct 2008.

[47] K. Tajeddini, "Customer orientation, learning orientation, and new service development: an empirical investigation of The Swiss Hotel industry," Journal of Hospitality \& Tourism Research, vol. 35, pp. 437-468, Nov 2011.
[48] Y.J. Ko, and D.L. Pastore, "A hierarchical model of service quality for the recreational sport industry," Sport Marketing Quarterly, vol. 14, pp. 84-97, 2005.

[49] A. Lapko, "Problems of yacht charter companies in Poland," European Journal of Service Management, vol. 1, pp. 165-172, 2018.

[50] A. Meesalaa and J.Paul, "Service quality, consumer satisfaction and loyalty in hospitals: thinking for the future," Journal of Retailing and Consumer Services, vol. 40, pp. 261-269, Jan 2018.

[51] E. Aydoğan and M. Kadığlu, "Yat turizminin turizm sektörü içerisindeki yeri ve önemi," Journal of Eta Maritime Science, vol. 6, pp. 243-254, Jul 2017. 